\title{
KEARIFAN LOKAL PADA ARSITEKTUR VERNAKULAR GORONTALO: Tinjauan Pada Aspek Budaya dan Nilai-nilai Islam
}

\author{
Heryati dan $\mathcal{N}$ urnaningsif $\mathcal{N}$ ico A6du \\ Universitas Negeri Gorontalo \\ email: heryati111@gmail.com
}

\begin{abstract}
This paper aimed to reveal the values of local wisdom in the vernacular architecture of Gorontalo. The research was conducted with a qualitative research method in which the data were grouped into physical and non-physical data. Physical data (tangible) is obtained by measuring, drawing, photo recording, and tracking documents, while the non-physical data (intangible) is gained through interviews with ta momayanga (the expert), basi lo bele (home builders), tauwa lo adati (traditional leader), community/religious figure, architects, academicians and through discussions. The data analysis is done by describing and interpreting the empirical evidence through the vernacular theories to figure out the vernacular concept of the stage house of Gorontalo. Furthermore, the theory of the relation of function, form and meaning is used to reveal the concept of local wisdom. The results show that the architecture of the stage houses contains vernacular factors loaded with the values of local wisdom that can be seen from the shape, layout, construction structure and ornamentation. The values of local wisdom was reinforced after the arrival of Islam in Gorontalo around 15-16 century.
\end{abstract}

Artikel ini bertujuan mengungkap nilai-nilai kearifan lokal dalam arsitektur vernakular Gorontalo. Penelitian dilakukan dengan metode penelitian kualitatif dimana data dikelompokkan menjadi data fisik dan non fisik. Data fisik (tangible) diperoleh dengan cara pengukuran, penggambaran, rekaman foto, dan penelusuran dokumen, sedangkan data non fisik (intangible) diperoleh melalui wawancara terhadap ta momayanga (ahli rumah), basi lo bele (tukang rumah), tauwa lo adati (tokoh adat), tokoh masyarakat/agama, arsitek, akademisi dan melalui diskusi-diskusi. Analisis data dilakukan melalui deskripsi dan 
interpretasi bukti empiris yang dikaji berdasarkan teori-teori vernakular untuk mengetahui konsep vernakular rumah panggung Gorontalo. Selanjutnya untuk mengungkap konsep kearifan lokal dilakukan melalui teori relasi fungsi, bentuk dan makna. Hasil penelitian menunjukkan bahwa arsitektur rumah panggung Gorontalo mengandung faktor-faktor vernakular yang sarat nilai-nilai kearifan lokal yang terlihat dari bentuk, tata ruang, struktur konstruksi dan ornamen. Nilai-nilai kearifan lokal ini semakin diperkuat setelah masuknya Islam di Gorontalo sekitar abad ke 15-16.

Keywords: local wisdom, architecture, vernacular

\section{Pendahuluan}

Hampir setiap bangunan dalam kurun waktu tertentu akan mengalami perubahan baik langsung maupun tidak langsung. Berubah akibat adanya proses adaptasi untuk menghadapi perubahan kebutuhan di tiap-tiap generasi ataupun karena faktor alam. Perubahan ini terjadi karena adanya perubahan peradaban, perubahan spirit zaman dan perubahan dari era lama ke era baru, misalnya dari era pertanian ke era industri, sehingga kemapanan secara ekonomis tentu berubah dan pada akhirnya berujung pada sebuah kebutuhan perubahan yang berimbas pada bangunan.

Dalam hubungan ini 2 elemen budaya perlu diidentifikasi secara cermat. Elemen pertama adalah inti budaya yang menolak untuk berubah. Lainnya adalah elemen budaya yang mampu berubah, tumbuh dengan cepat tetapi perlu didorong untuk mampu menghadapi tantangan dari luar tanpa kehilangan jiwa roh jati dirinya.

Jati diri atau identitas merupakan "jejak" yang ditinggalkan oleh peradaban, bergerak sejalan dengan sejarah dan merupakan sebuah "proses" yang tidak terjadi dengan sendirinya tetapi bertolak dari logika yang dikuti oleh masyarakatnya. Jati diri lahir dan tumbuh dari pengertian terhadap diri sendiri, dan masyarakat lingkungannya (Wiranto, 1999: 17).

Secara konsepsual, kearifan lokal dan keunggulan lokal merupakan kebijaksanaan manusia yang bersandar pada filosofi nilai-nilai, etika, caracara dan perilaku yang melembaga secara tradisional. Kearifan lokal adalah nilai yang dianggap baik dan benar sehingga dapat bertahan dalam waktu yang lama dan bahkan melembaga. Kearifan-kearifan lokal pada dasarnya dapat dipandang sebagai landasan dalam pembentukan jati diri bangsa secara nasional. Kearifan-kearifan lokal itulah yang membuat suatu budaya bangsa memiliki akar (Sartini, 2004:112). Untuk memahami kearifan lokal pada suatu karya arsitektur perlu ditelusuri konsep konsep yang melatar belakangi 
lahirnya karya tersebut.

Arsitektur vernakular dan jati diri bersama tumbuh dari aspirasi rakyatnya dan mengacu pada masalah-masalah yang nyata tentang lingkungan, iklim dan aspirasi masyarakatnya. Dalam hal ini iklim merupakan faktor yang penting, karena iklim membantu menentukan "bentuk", baik secara langsung maupun dalam aspek budaya dan ritual. Masyarakat senantiasa berkembang dan berubah namun iklim selalu tetap (Yeang, 1983:14-15).

Terkait dengan arsitektur vernakular beberapa konsep terkait hunian yang dihasilkan dan sering dirujuk oleh para peneliti arsitektur dalam memahami konsep-konsep hunian antara lain modifying factor (Rapoport, 1969), sociocultural factors (Morgan, 1965), symbolic conceptions (Griaule/ Dieterlen, 1963), multiple factor thesis (Schefold,1997), cosmos-symbolism (Eliade, 1959), social organization (Durckheim/Mauss,1925; Rassers,1982; Cunningham, 1964), dan gender-symbolism (Bourdieu, 1972). Berdasarkan seluruh pendapat para ahli merumuskan konsep vernakular dalam Tabel 1 tersebut (Mentayani dan Ikaputra , 2012: 72).

Tabel 1. Konsep-konsep Terkait Hunian Vernakular

\begin{tabular}{|c|c|c|}
\hline No & Konsep Vernakular & DESKRIPSI KONSEP-KONSEP \\
\hline 1. & $\begin{array}{l}\text { Factor analysis } \\
\text { (Rapoport) }\end{array}$ & $\begin{array}{l}\text { Bentuk-bentuk atau model vernakular disebabkan } \\
\text { oleh enam faktor yang dikenal sebagai modifying } \\
\text { factor (Rapoport, 1969: 78), diantaranya } \\
\text { adalah: Faktor Bahan, Metode Konstruksi, Faktor } \\
\text { Teknologi, Faktor Iklim, Pemilihan Lahan, Faktor } \\
\text { sosial-budaya }\end{array}$ \\
\hline 2. & $\begin{array}{l}\text { Sociocultural factors } \\
\text { (Morgan) }\end{array}$ & $\begin{array}{l}\text { Bentuk rumah (vernakular) sangat berkaitan dengan } \\
\text { pola perilaku budaya, nilai-nilai budaya, dan } \\
\text { sudut pandang terhadap dunia mereka. }\end{array}$ \\
\hline 3. & $\begin{array}{l}\text { Symbolic conceptions } \\
\text { (Griaule/ Dieterlen) }\end{array}$ & $\begin{array}{l}\text { Terdapat konsep-konsep simbolik, yaitu konsep } \\
\text { yang berhubungan dengan alam semesta, sebagai } \\
\text { sudut pandang dalam melihat dan menuntut } \\
\text { proses pembangunan rumah. }\end{array}$ \\
\hline 4. & $\begin{array}{l}\text { Multiple factor thesis } \\
\text { (Schefold) }\end{array}$ & $\begin{array}{l}\text { Terdapat beberapa faktor dalam menjelaskan } \\
\text { bentuk rumah. Salah satunya merupakan faktor } \\
\text { utama. }\end{array}$ \\
\hline
\end{tabular}




\begin{tabular}{|c|l|l|}
\hline 5. & $\begin{array}{l}\text { Cosmos-symbolism } \\
\text { (Eliade) }\end{array}$ & $\begin{array}{l}\text { Rumah merupakan refresentasi simbolik dari 3 } \\
\text { unsur kosmos, yaitu surga/dunia atas, dunia } \\
\text { manusia, dan dunia bawah. Ketiga simbol kosmos } \\
\text { ini tersimbolkan melalui atap, ruang-ruang dalam, } \\
\text { dan bagian bawah rumah. }\end{array}$ \\
\hline 6. & $\begin{array}{l}\text { Social organisation } \\
\text { Durckheim/ Mauss, } \\
\text { Rassers; } \\
\text { Cunningham) }\end{array}$ & $\begin{array}{l}\text { Menunjukkan adanya klasifikasi simbolik yang } \\
\text { meliputi bagian yang suci, tertutup, dan bagian } \\
\text { anita. Konsep simbolik ini sangat berkaitan } \\
\text { dengan } \\
\text { dimensi makrokosmos. }\end{array}$ \\
\hline 7. & $\begin{array}{l}\text { Gender-symbolism } \\
\text { (Bourdieu) }\end{array}$ & $\begin{array}{l}\text { Adanya karakteristik yang sangat kuat yang } \\
\text { menunjukkan simbol perbedaan jenis kelamin } \\
\text { (gender). }\end{array}$ \\
\hline
\end{tabular}

Sumber: Mentayani dan Ikaputra (2012:72)

Berdasarkan berbagai konsep di atas maka saat ini arsitektur vernakular dapat disimpulkan sebagai arsitektur yang memiliki sifat kelokalan. Arsitektur vernakular adalah desain arsitektur yang menyesuaikan iklim lokal, menggunakan teknik dan material lokal, dipengaruhi aspek sosial, budaya, dan ekonomi masyarakat setempat.

Berbagai macam konsep yang dapat diidentifikasikan sebagai dasar pertimbangan terbentuknya vernakular di atas memiliki pengaruh pada arsitektur vernakular yang berbeda-beda tergantung dari lokasi yang berlainan. Perbedaan lokasi ini sangat besar pengaruhnya pada arsitektur vernakular.

Indonesia adalah salah satu negara yang memiliki banyak ragam arsitektur vernakular. Hampir setiap daerah di Indonesia memiliki arsitektur tradisional yang berbeda-beda. Semuanya memiliki arsitektur yang berciri khas yang berbeda-beda yang dipengaruhi oleh berbagai aspek-aspek sebagaimana deskripsi konsep vernakular pada tabel 1 di atas.

Masyarakat Gorontalo memiliki arsitektur lokal berbentuk panggung yang dikenal dengan nama rumah "Budel". Budel adalah istilah masyarakat lokal dalam menyebut rumah dalam hal statusnya sebagai rumah warisan yang tidak memiliki hak kepemilikan yang jelas karena ketika pemilik utama (orang tua) meninggal dunia tidak sempat meninggalkan hak waris kepada keturunannya sehingga biasanya hanya sekedar untuk dihuni secara turun temurun oleh anak, cucu, dan keturunan-keturunan selanjutnya. Namun 
tidak semua rumah Budel adalah arsitektur lokal. Masih banyak rumah-rumah bergaya kolonial peninggalan zaman Belanda di Gorontalo yang juga disebut sebagai Rumah Budel karena statusnya.

Arsitektur rumah yang berbentuk panggung inilah yang menjadi saksi sejarah peradaban masyarakat Gorontalo pada zaman dahulu. Terbentuknya rumah panggung ini dipengaruhi oleh berbagai aspek seperti yang mempengaruhi terbentuknya arsitektur vernakular pada umumnya.

\section{Aspek Sejarah sebagai Pembentuk Kearifan Lokal Terbentuknya Kerajaan Gorontalo}

Sebelum masa penjajahan Belanda keadaan daerah Gorontalo berbentuk kerajaan-kerajaan yang diatur menurut hukum adat ketatanegaraan Gorontalo. Kerajaan-kerajaan itu tergabung dalam suatu ikatan kekeluargaan yang disebut "pohala'a".

Ada lima pohala'a yang ada di daerah Gorontalo yang kemudian dikenal dengan nama Limo lo Pohala'a yang terdiri dari; Pohala'a Gorontalo, Pohala'a Limboto, Pohala'a Suwawa (Bone, Suwawa, dan Bintauna), Pohala'a Bolango (tahun 1862 digantikan Bualemo) dan Pohala'a Atinggola. Istilah lain yang ada menyebutkan Duo Limo lo Pohala'a yang artinya dua kerajaan inti dari lima bersaudara yakni kerajaan Gorontalo dan kerajaan Limboto. Istilah ini muncul setelah dua kerajaan besar tersebut membuat perjanjian damai setelah terlibat dalam peperangan panjang dimana pada saat itu Limboto dibantu oleh Raja Ternate sementara Gorontalo dibantu oleh Raja Gowa.

Dalam pemerintahan kerajaan Gorontalo, terdapat badan-badan pelaksana yang mengemudikan LIPU (kerajaan), antara lain mengatur politik, perputaran ekonomi, peningkatan keamanan dan pertahanan serta sosial budaya. Badan-badan pelaksana ini disebut U-LIPU yang dikepalai oleh Olongia (Raja) (Daulima, 2004: 3).

Dalam persekutuan Linula (kerajaan-kerajaan kecil), sumber hukum menonjol ialah "Balata" yakni tata sila yang ditentukan dari atas, tanpa mengurangi keinginan-keinginan rakyat. Untuk mengoreksi hal ini, dibuatlah Dewan Perwakilan Rakyat dengan "Banthayo Poboide" (Tempat dan Badan Musyawarah). Demikian sistem kerajaan berlangsung hingga awal abad ke18 (tahun 1824), daerah Limo Lo Pahala'a telah berada di bawah kekuasaan Asisten Residen, disamping pemerintahan tradisional (Daulima, 2006: 111). Pada tahun 1889 sistem pemerintahan kerajaan dialihkan ke pemerintahan langsung yang dikenal dengan istilah "Rechtatreeks Bestur". Pada tahun 1911 
terjadi lagi perubahan dalam struktur pemerintahan, daerah Limo Lo Pohala'a dibagi lagi atas 3 (tiga) Onder Afdeling yaitu: Onder Afdeling Kwandang, Onder Afdeling Gorontalo, Onder Afdeling Boalemo. Perubahan Administrasi pemerintahan ini seterusnya berlangsung sampai meletusnya perang dunia ke II.

Dari lima Pohala'a yang ada masing-masing memiliki penggolongan masyarakat, namun pada akhir pemerintahan Belanda sebelum peristiwa 23 Januari 1942, rakyat Gorontalo hanya dapat digolongkan terbagi atas 4 golongan, yaitu:

1. Golongan Mongoeyo (bangsawan).

2. Golongan Udula'a (golongan kepala kampung, termasuk golongan menengah bukan dari golongan bangsawan dan bukan dari golongan budak/wato).

3. Golongan Wali-wali, termasuk pegawai-pegawai, dokter, insinyur, dan lain-lain, yang berstatus udula'a dan tuango-lipu, adalah Mantri Tani, Mantri Hewan, Mantri Cacar dan Juru Tulis.

4. Golongan Tuwango Lipu, yaitu golongan rakyat biasa yang berhak mendapat jabatan Kepala Kampung, dan jabatan Syara di bawah Kadhi, Moputi dan Imam. Tetapi tidak dibatasi, apabila mereka ahli dan berbudi pekerti yang baik dapat menempati jabatan yang lebih di atas.

Penggolongan masyarakat pada zaman kerajaan di Gorontalo tersebut memberikan pengaruh pada tipe bangunan, bentuk bangunan, bentuk atap, formasi dan jumlah tiang, dimensi ruang/rumah, serta bentuk ornamen rumah panggung.

Hasil wawancara dengan Farhah Daulima (budayawan Gorontalo) bahwa berdasarkan strata sosial orang yang mendiami rumah pada masyarakat Gorontalo pada zaman dahulu, rumah (Bele) digolongkan menjadi:

1. Bele Yiladea, jenis rumah yang dihuni oleh raja pada pusat-pusat kerajaan di setiap kabupaten.

2. Bele Lo ti duulu, yakni rumah yang dihuni oleh kepala kampung, dilengkapi dengan penodopo.

3. Bele Pitu lo palata (rumah tujuh buah atap rumbia, 1 atap panjangnya 3 meter berarti panjang rumah $7 \times 3$ meter $=21$ meter), dan lebar $60 \mathrm{~cm}$ berarti $7 \times 60$ berarti $4,20 \mathrm{~m}$, yakni jenis rumah yang dihuni oleh orang kaya.

4. Bele Dupi, yakni jenis rumah yang ditinggali oleh masyarakat kebanyakan. 
Namun demikian berdasarkan pengamatan di lapangan, pengklasifikasian menurut penggolongan masyarakat secara fisik sebagaimana tersebut di atas sudah tidak ditemukan lagi. Sebagian besar yang tersisa hanya rumah panggung milik masyarakat kebanyakan dan beberapa rumah turunan bangsawan dan turunan kepala kampung yang dapat diidentifikasi dari hasil wawancara dengan pemilik rumah mengenai riwayat rumah termasuk pemilik pertama rumah tersebut, hanya sebagian kecil teridentifikasi dari ciri fisik bangunannya seperti dimensi rumah dan ornamen/ragam hiasnya.

Pada masa yang sama masuknya Belanda ke Gorontalo perlahan-lahan memberi pengaruh dalam penggunaan material dimana sebelumnya elemen tiang, lantai, dan dinding menggunakan material kayu, serta bagian atap menggunakan material rumbia. Setelah masuknya Belanda material-material tersebut lebih didominasi dengan konstruksi batu bata semantara atap menggunakan atap seng. Akulturasi lainnya terlihat pada dimensi bukaanbukaan yang lebar dengan model-model bukaan yang bergaya kolonial.

\section{Masuknya Islam di Gorontalo}

Jauh sebelum agama Islam masuk dengan segala pengaruh yang dibawanya ke Gorontalo, penduduk suku Gorontalo tidak jauh berbeda dengan sukusuku di Indonesia, yang bertebar di seluruh kepulauan Nusantara. Berdasarkan kenyataan historis sebelum terdapat pengaruh agama Islam, sikap dan watak serta perbuatan penduduk di Gorontalo seperti juga terlihat pada kebiasaan bangsa-bangsa lainnya. Masyarakat suku Gorontalo sangat menghormati unsur penguasa, pemuka adat, dan orang tua. Hal ini didasarkan kepada kepercayaan tradisional, terlihat juga pada cerita rakyat dan puisi lisan.

Pada masa Eyato (1673) menjadi raja persatuan u duluwo limo lo Pohala'a dan raja kesatuan Gorontalo-Limboto agama Islam resmi menjadi agama kerajaan. Adat sebagai wujud kebudayaan yang disebut juga sistem budaya adalah sama dengan prinsip adat bersendikan syarak, syarak bersendi Kitabullah (al Quran)". Istilah ini dalam bahasa Gorontalo disebutkan "Adati hula-hula'a to sara'a, sara'a hula-hula'a to kuru'ani". Dalam kenyataan sejarah istilah ini tidak muncul dengan sendirinya, akan tetapi melalui suatu proses sejarah (Baruadi, 2102: 296). Pada masa Gorontalo diperintah oleh Sultan Amai (1523-1550) slogannya adalah "sara'a topa-topango to adati" atau syarak bertumpu pada adat (Nur dalam Baruadi, 2012: 296). Raja Gorontalo yang pertama kali menerima tentang risalah Islam masuk ke kerajaan Gorontalo adalah Sultan Amai pada awal abad ke-16 atau tahun 1525 (Ibrahim, 2004: 57). 
Pada masa pemerintahannya Sultan Eyato dalam falsafah pelaksana kekuasaannya memandang bahwa negara sebagai organisasi kekuasaan dan kepala negara adalah wakil Tuhan di negara itu untuk menyelamatkan umat manusia dalam hal ini masyarakat penduduk negeri itu. Oleh sebab itu, pelaksana kekuasaan dalam hal ini pejabat pemerintahan harus dibajukan (Pilo Pobo'o Liyo) sifat-sifat Tuhan, dan harus bekerja sesuai sifat Tuhan, yang terbagi atas: Sifat Nafsia, Sifat Salbiya, Sifat Ma'ani dan Sifat Ma'anawiya. Sifat-sifat inilah yang dikukuhkan dalam sumpah pada setiap pelantikan dan pemberian gelar (Daulima, 2004:13). Sifat-sifat itu menjadi sifat dan sikap semua aparat kerajaan mulai dari pejabat tertinggi sampai dengan dengan jabatan terendah (Nur, 1979: 104).

Bagi masyarakat $u$ duluwo limo lo Pohala'a Gorontalo pada masa Eyato "syarak kitabullah" dipahami dan diakui sebagai hukum dan aturan-aturan yang menjadi ajaran yang bersumber dari kitab suci al Quran dan al Hadits Rasulullah SAW. Penerapan adat (sistem budaya) Islam pada sikap dan perilaku pejabat seperti yang telah dikemukakan sebelumnya telah mengawali pemantapan karakteristik budaya Islam dalam kehidupan masyarakat Gorontalo termasuk budaya dalam berarsitektur. Masuknya Islam di Gorontalo semakin memperkuat nilai-nilai budaya termasuk nilai-nilai/filosofi yang mendasari setiap bentuk, tata ruang rumah, penentuan jumlah/susunan setiap elemen-elemen rumah dan tradisi-tradisi yang mengikuti proses membangun.

\section{Aspek Iklim, Geografi, dan Topografi}

Bentuk Topografi Kota Gorontalo relatif datar dan memiliki ketinggian 0-50 meter dari permukaan laut. Kondisi dan struktur utama geologi adalah patahan yang berpotensi menimbulkan gerakan tektonik sehingga menyebabkan rawan bencana alam seperti gempa bumi, gerakan tanah, erosi, abrasi, dan gelombang pasang serta pendangkalan dan banjir. Ketinggian ini menjadikan beberapa tempat di wilayah ini rawan terhadap banjir apalagi pada musim hujan, ditambah lagi dengan wilayah Kota Gorontalo dilalui oleh tiga sungai besar yaitu Sungai Bone berukuran panjang $3,40 \mathrm{~km}$, Sungai Bolango $10,00 \mathrm{~km}$, dan Sungai Tamalate $5 \mathrm{~km}$, ketiga sungai ini bermuara di Teluk Gorontalo.

Kota Gorontalo terletak dekat dengan titik garis khatulistiwa dan menjadikan daerah ini sering mengalami panas yang cukup panjang dengan iklim tropis lembab. Keadaan temperatur rata-rata minimum 23,200 celcius dan maksimum 32,600 celcius. Kelembaban udara relatif tinggi mencapai $79,22 \%$ dengan curah hujan tertinggi terjadi pada bulan Maret dengan 389 
$\mathrm{mm}$ per jumlah hari hujan sebanyak 30 hari. Kecepatan angin setiap bulannya berkisar antara 1.00-3,00 m/dt (BPS Propinsi Gorontalo, 2013: 5).

Iklim daerah Gorontalo memiliki pengaruh terhadap bentuk keseluruhan rumah tradisional Gorontalo. Rumah berbentuk panggung dengan ketinggian panggung sekitar $1,5 \mathrm{~m}$ di atas permukaan tanah. Ruangan di bawah lantai selain difungsikan sebagai tempat menyimpan alat pertanian, nelayan dan hasil bumi. Kolong rumah juga dibuat tinggi untuk memberikan hawa yang segar, terutama pada musim panas, di samping itu agar lebih aman dalam menghadapi bahaya banjir. Tritisan atap utamanya atap teras dibuat lebar dengan dominasi bukaan pada dinding, terdapat bukaan di bawah atap juga sebagai bentuk adaptasi terhadap iklim tropis lembab. Selain itu kondisi geologi dan geografi wilayah Gorontalo mengakibatkan sering terjadi gempa-gempa kecil sehingga pemilihan material serta sistem struktur-konstruksi dengan sistem pasak dan pen dibuat untuk mengantisipasi ancaman gempa.

\section{Kehidupan Sosial Budaya}

Secara faktual, kesediaan dan kerelaan masyarakat Gorontalo untuk selalu hidup berdampingan secara damai dengan masyarakat dan kelompok yang berbeda dengan kelompoknya, kelompok yang bervariasi atau serba multi (agama, suku, identitas, tradisi, budaya dan lain-lain) sesungguhnya sudah diperlihatkan secara adat dalam tatanan $u$ duluwo limo lo pohala'a, (lima kerajaan di Gorontalo yang difungsikan sebagai dua kekuatan dalam membangun Gorontalo dalam mengaktualisasikan kehidupan nyata masyarakat Gorontalo yang damai, bernuansa kekeluargaan, menjunjung kelestarian, penuh toleransi, solidaritas, demokratis sebagaimana dicita-citakan serba diharapkan oleh seluruh warganya. Sifat keterbukaan orang Gorontalo dalam membangun interaksi dengan warga kelompok lain sesungguhnya merupakan wujud dari upaya mereka menjaga keseimbangan kosmos. Dalam pengertian kebiasaan mereka yang cenderung selalu memelihara hubungan kemasyarakatan, baik dalam inter dan antar suku-suku, kelompok-kelompok, dimaksudkan untuk mencapai keluhuran sejati melalui kesetiaan atau ketaatan dengan menjalankan hukum adat/agama dengan meletakkan falsafah "adat bersendikan syara' dan syara' bersendikan kitabullah" berarti tata krama kesopanan dalam pergaulan yang berkeadaban sebagai pedoman dalam menciptakan interaksi dalam kehidupan sosial masyarakat, sedangkan adat yang telah menjadi tradisi dan berkembang di Gorontalo harus dilandasi dengan nilai-nilai syariat agama. 
Dulohupa (musyawarah) adalah salah satu bentuk manajemen konflik di kalangan suku Gorontalo, yaitu suatu upaya mereka untuk menghindari terjadinya konflik baik di dalam kelompok maupun di luar. Karakter dulohupa dimaknai sebagai berikut: (1) Upaya mereka dalam menghindari terjadinya berbagai konflik antar manusia dengan segala unsur yang ada dalam kosmos. (2) Bentuk tanggung Jawab mereka kepada nenek moyang, roh-roh di sekeliling mereka, terhadap sesama manusia dan terhadap Tuhan Yang Maha Esa. (3) Mereka memiliki toleransi yang sangat tinggi terhadap sesama dan orang luar datang ke lingkungan. (4) Bagian dari budaya "dulohupa" yang melambangkan keterbukaan dan menghargai kebhinekaan tanpa melihat perbedaan suku, agama, dan asal usul. (5) Bentuk ketaatan orang Gorontalo terhadap adat dan nilai-nilai yang terkandung dalam religi. Mereka tidak rela disebut "dila o adabu" (manusia hidup tidak beradat) (Tohopi, 2012: 151).

Selain itu, terdapat beberapa aturan yang harus diutamakan, yaitu mo potawu lo tawu, (menghormati orang lain), dahayi lipu odungga lo bala (jagalah kampung dari mara bahaya), dahayi batanga wawu dilipata parentha lo Eyaa (jaga diri dan laksanakan perintah Allah SWT). Dalam tindakan aspek sosial keagamaan secara adat masyarakat suku Gorontalo diajak untuk melaksanakan konsep batanga/nyawa po maya (jiwa raga/badan manusia untuk pengabdian), lipu peyi hulalo (membangun daerah/kampong), agama potombulu (agama sebagai pedoman hidup) artinya konsep diatas sebagai motivator atau spirit dalam menjalankan aktivitas kemasyarakatan (Tohopi, 2012: 152).

Ajaran tersebut juga mencerminkan pemahaman pentingnya kehidupan harmonis dalam rangka menjaga keseimbangan kosmos yang dalam kehidupan bermasyarakat terlibat secara jelas, yakni dikedepankannya pola hubungan kerja sama, dalam bentuk huyula motiayo, gotong royong, atau saling membantu. Sistem gotong royong ini bertujuan untuk saling meringankan beban bagi sesama masyarakat yang sedang menghadapi suatu pekerjaan atau musibah contohnya pekerjaan membangun rumah, tempat ibadah, atau menghadapi peristiwa kedukaan. Kegiatan gotong royong tidak hanya melibatkan pada satu keluarga batih (ngala'a) atau keluarga luas (ungala'a) tetapi juga pada suatu kelompok masyarakat yang lebih luas di daerah ini. Budaya musyawarah (dulohupa) sampai sekarang secara fisik masih dapat dilihat pada bangunan yang sengaja dibuat untuk pelaksanaan musyawarah adat yang dikenal dengan nama Rumah Adat Dulohupa. 


\section{Nilai-nilai Sejarah, Budaya dan Nilai-nilai Islam sebagai Wujud Kearifan Lokal pada Arsitektur Vernakular Gorontalo}

Kearifan lokal (local genius) adalah kebenaran yang telah mentradisi atau ajeg dalam suatu daerah. Kearifan lokal merupakan perpaduan antara nilainilai suci firman Tuhan dan berbagai nilai yang ada. Kearifan lokal terbentuk sebagai keunggulan budaya masyarakat setempat maupun kondisi geografis dalam arti luas. Kearifan merupakan produk budaya masa lalu yang patut secara terus-menerus dijadikan pegangan hidup. Meskipun bernilai lokal tetapi nilai yang terkandung di dalamnya dianggap sangat universal. Kearifan lokal merupakan suatu gagasan konseptual yang hidup dalam masyarakat, tumbuh dan berkembang secara terus menerus dalam kesadaran masyarakat, berfungsi dalam mengatur kehidupan masyarakat dari yang sifatnya berkaitan dengan kehidupan yang sakral sampai yang profane (Sartini, 2004: 112-113).

Arsitektur vernakular Gorontalo merupakan arsitektur peninggalan masa lalu yang terbentuk melalui proses akulturasi nilai-nilai budaya lokal Islam dan kolonial. Nilai-nilai lokal adalah nilai-nilai yang lahir dari tradisi dan mengalami penguatan setelah masuknya Islam di Gorontalo. Hal ini diperkuat dengan data sejarah tentang masuknya Islam pada sekitar abad ke 15-16, dan kolonial abad ke-18 di Gorontalo.

Tradisi bukan sekedar adat atau kegemaran dan juga bukan suatu gaya sekejap yang mengisi suatu periode waktu saja, tetapi sesuatu yang menerus, menyeluruh dan elemen utamanya adalah "agama" (Nasr, 1973: 9-10). Arsitektur vernakular Gorontalo merupakan pengembangan dari arsitektur rakyat memiliki nilai ekologis, arsitektonis dan "alami" karena mengacu pada kondisi, potensi Iklim-Budaya dan masyarakat lingkungannya. Arsitektur rumah panggung Gorontalo secara langsung telah mendapatkan "pengakuan" masyarakatnya karena tumbuh dan melewati perjalanan pengalaman "trial and error" yang panjang. Dimulai saat Gorontalo masih berupa lautan kemudian muncul sebagai sebuah daratan yang dihuni oleh pendatang-pendatang yang berasal dari Sulawesi Utara, Gowa dan Bone (saat terjadi pertikaian kerajaan Gorontalo dan Limboto), sampai pada saat Gorontalo mencapai puncaknya dipimpin oleh Raja Eyato yang berhasil mendamaikan 2 kerajaan yang bertikai, dan pada zaman ini agama Islam resmi menjadi agama kerajaan di Gorontalo (abad 15-16). Pada akhirnya perlahan-lahan sistem pemerintahan kerajaan diambil alih pemerintahan kolonial abad 18-19.

Perjalanan sejarah Gorontalo inilah yang mewarnai bentuk arsitektur vernakular Gorontalo, yang mengandung muatan "local genius" dan nilai 
jati diri yang mampu menampilkan rona asli, berbeda beda dan bervariasi. Arsitektur ini sangat dekat dengan budaya lokal yang umumnya tumbuh dari masyarakat Gorontalo. Ini sejalan dengan apa yang dikatakan oleh seorang ahli vernakular:

"Vernacular architecture is a generalized way of design derived from Folk Architecture, it uses the design skills of Architects to develop Folk Architecture (Allsopp, 1977: 6).

Arsitektur vernakular Gorontalo merupakan sosok lingkungan binaan yang lahir dari nilai-nilai tradisi yang kemudian berkembang melalui proses akulturasi budaya-budaya luar (Belanda, Arab, Cina, Bugis-Makassar, Sulawesi Utara) dan budaya lokal. Akulturasi budaya ini terekspresi pada sosok bentuk arsitektur vernakular Gorontalo mulai dari bentuk sampai pada penggunaan ornamen/ragam hias.
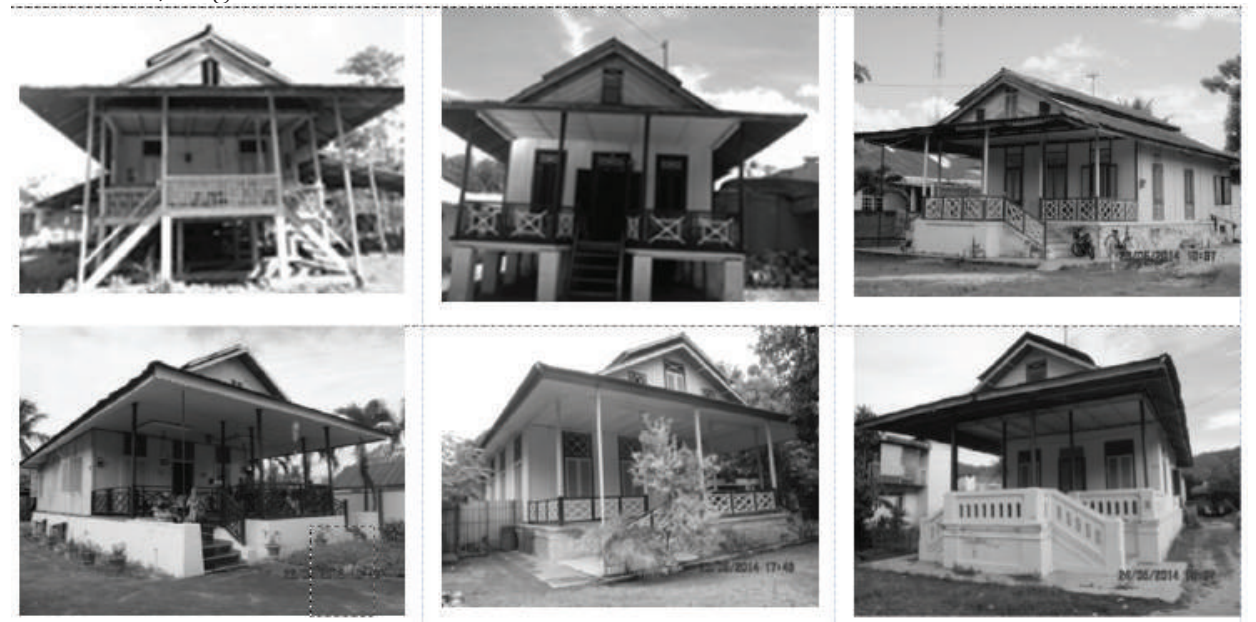

Gambar 1. Variasi Bentuk Rumah Panggung Masyarakat Gorontalo

Dalam konteks rumah tradisional, kearifan lokal yang menyertai proses pembangunan rumah panggung Gorontalo sudah mengatur harmonisasi antara kebutuhan teknologi, bahan bangunan, desain, tata letak, dengan kemampuan alam. Harmonisasi dicapai oleh masyarakat Gorontalo dengan terlebih dahulu mengenal dan memahami dengan baik kondisi lingkungannya. Masyarakat sangat menguasai konsep ekologi dimana mereka hidup. Mereka mengetahui dengan baik interaksi antara makhuk hidup dengan lingkungan biotik dan abiotiknya, sehingga tercipta kehidupan yang seimbang, serasi dan selaras. Sikap masyarakat Gorontalo ini akan memberikan gambaran secara menyeluruh bagaimana orang Gorontalo dalam bertindak bersikap, 
sikap inilah yang merupakan turunan dari falsafah hidupnya dengan segala makna yang ada.

Dalam kajian teori arsitektur makna ditempatkan sebagai aspek yang utama dalam arsitektur selain fungsi dan bentuk. Makna menjadi bagian yang fundamental dalam hidup manusia, karenanya manusia selalu membubuhkan makna pada apapun yang diberikan kepadanya; manusia tidak pernah mendapatkan dalam kesadarannya sesuatu yang tidak bermakna dan dirujuk di luar dirinya (Capon, 1999: 110). Dalam segitiga hubungan fungsi-bentukmakna; aspek fungsi selalu berkaitan dengan konteks, aspek bentuk berkaitan dengan struktur dan makna berhubungan dengan interpretasi dari fungsi dan bentuk arsitektur tersebut.

Sehubungan dengan penjelasan di atas secara keseluruhan sikap masyarakat Gorontalo dalam bersikap dan bertindak melahirkan bentuk arsitektur rumah panggung Gorontalo yang di dalamnya tersirat nilai-nilai yang mengatur relasi manusia dengan Tuhan, alam, masyarakat dan sebagai pribadi. Relasi manusia dengan Tuhan, alam, masyarakat dan sebagai pribadi masing-masing diterjemahkan dengan makna yang tersirat didalamnya. Makna ini kemudian menghasilkan bentuk kegiatan dan wadahnya yang terwujud dalam arsitektur vernakular Gorontalo dengan segala pelingkupnya.

Sebagai bentuk perwujudan dari sikap tersebut pada arsitektur vernakular Gorontalo sebagai hasil terjemahan dari makna yang tersirat pada masingmasing relasi dapat dijelaskan sebagai berikut:

1. Bagaimana masyarakat Gorontalo berelasi dengan Tuhan yang merupakan penyatuan nilai-nilai luhur (kebaikan) terhadap diri manusia, sehingga bentuk dari penyatuan nilai-nilai ini diwujudkan dalam bentuk pola ruang yang berbentuk segi empat pertanda empat kekuatan alam yakni air, api, angin, dan tanah. Tidak ada aturan untuk jumlah kamar kecuali pada saat awal mula pembangunan rumah tidak diperkenankan membuat kamar lebih dari 3 kecuali rumah bangsawan, penambahan kamar dilakukan belakangan setelah rumah itu dihuni. Angka tiga di masyarakat Gorontalo memiliki makna filosofis tiga dimensi kehidupan manusia yaitu sistem tolo lenggota yang terdiri atas lenggota bohuliyo (dimensi pertama) yang berarti dari tidak ada, lenggota oluwoliyo (dimensi kedua) kemudian ada, dan lenggota otoluliyo (dimensi ketiga) kembali kepada tiada. Hakekat dari tolo lenggota ini adalah mencari ketiga kehormatan Sang Pencipta dengan tiga ilmu utama yaitu ilmu mengenal diri sendiri, ilmu mengenal Tuhan (Sang pencipta alam semesta), dan yang terakhir adalah ilmu mengenal 
alam ciptaan-Nya. Manivestasi dari kepercayaan masyarakat Gorontalo ini terlihat dari adanya kamar pada bagian belakang yang umumnya berada pada petak peralihan, difungsikan sebagai kamar tempat memandikan mayat dan tradisi ini tidak hanya ditemui pada rumah panggung, tetapi juga pada rumah-rumah sekarang yang tidak berbentuk panggung.

Dari segi tata ruang, menurut penuturan para tua-tua, di masa lalu para perempuan Gorontalo (istri maupun anak) tidak boleh menerima tamu laki-laki jika bapak atau suami tidak berada di dalam rumah karena kekhawatiran akan timbulnya fitnah yang dapat mengakibatkan keretakan dan kekacauan dalam rumah tangga sehingga pada petak ruang antara ruang tamu (duledehu) dan petak ruang tidur (huwali) dibatasi oleh sebuah pintu sebagai hijab/pembatasnya. Maka jenis ruang yang muncul mewakili siklus kehidupan dan aktivitas para perempuan hanyalah sesuai kebutuhan yaitu ruang tidur dan dapur. Aturan untuk tidak memperkenankan tamu laki-laki masuk ke dalam rumah (tamu laki-laki di seramb/teras) adalah merupakan ajaran Islam yang tidak memperkenankan yang bukan muhrim masuk ke dalam rumah. Ini menunjukkan bahwa ajaran agama Islam sudah diberlakukan sebagai suatu adat yang tidak boleh dilanggar.

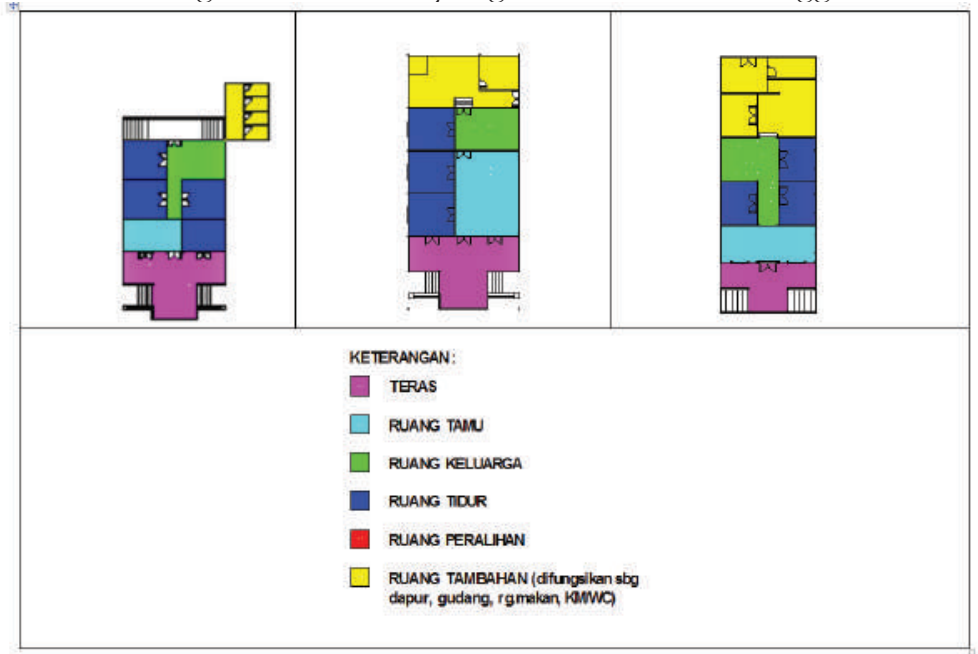

Gambar 2. Makna Relasi dengan Tuhan Pada Tata Ruang Horisontal

Terkait dengan letak kamar yang diletakkan berjejer ke belakang atau posisi bersilang dan saling berhadapan, posisi kamar tidur orang tua atau anak laki-laki berada pada bagian paling depan kemudian menyusul untuk anak-anak perempuan. Terlihat gambaran bahwa ruang tidur merupakan 
ruang yang sangat rahasia di dalam rumah sehingga tidak dibenarkan (tabu) bagi anak memasuki ruang tidur orang tua demikian pula sebaliknya orang tua laki-laki atau saudara laki-laki tidak dibenarkan memasuki ruang tidur anak atau saudara perempuan. Pada sebagian masyarakat di jaman dahulu, anak laki-laki tidak mendapat porsi ruang tidur karena sejak aqil balik sudah diharuskan untuk bekerja, menuntut ilmu agama dan tinggal di mesjid atau surau, sekalipun ada porsinya, ruang tidur anak laki-laki diletakkan paling depan dan diupayakan tidak berdekatan dengan ruang tidur anak perempuan. Perwujudan nilai-nilai Islam lainnya terdapat pada fungsi ruang teras/serambi. Di ruang ini ayah dan ibu, kakek dan nenek berkumpul menasehati para anak dan cucu melalui cerita dongeng atau cerita-cerita lainnya yang bertujuan mendidik dan menyusun rencana kegiatan dihari esok. Pada bulan Ramadhan difungsikan sebagai tempat mengaji, serambi depan (hihibata) untuk orang dewasa dan di serambi samping (hantaleya) untuk anak-anak.

Pembeda fungsi ruang diperkuat dengan adanya Pihito berupa balok yang menonjol di atas lantai yang berfungsi sebagai pembatas dari fungsi ruang menandakan bahwa aspek privasi sudah menjadi perhatian utamanya setelah masuknya Islam.

Filosofi angka 2, 3, 5, 6, 7, 8, pada pembentukan rumah. Penerapan angka-angka ini terdapat pada 8 tiang (wolihi) yang mendukung atap teras, diantara 8 tiang ini terdapat 2 tiang berdiri bebas (kode A) mendukung atap teras pada sudut kiri dan kanan terbuat dari besi, dan 6 lainnya (kode B) diikat dengan railing teras terbuat dari kayu, kearah belakang mulai dari kode $\mathrm{C}$ adalah merupakan tiang dasar (Potu) dengan konstruksi batu bata jumlahnya bervariasi tergantung besar rumah; jumlah kamar pada awal pembangunan rumah tidak boleh melebihi 3 kamar kecuali rumah raja; filosofi angka 7 pada struktur dan konstruksi; jumlah anak tangga bervariasi tergantung ketinggian umumnya terdiri dari 3, 5, 7 anak tangga; atap bersusun dua, dan penetapan-penetapan ukuran panjang dan lebar rumah pada proses mendirikan rumah. 

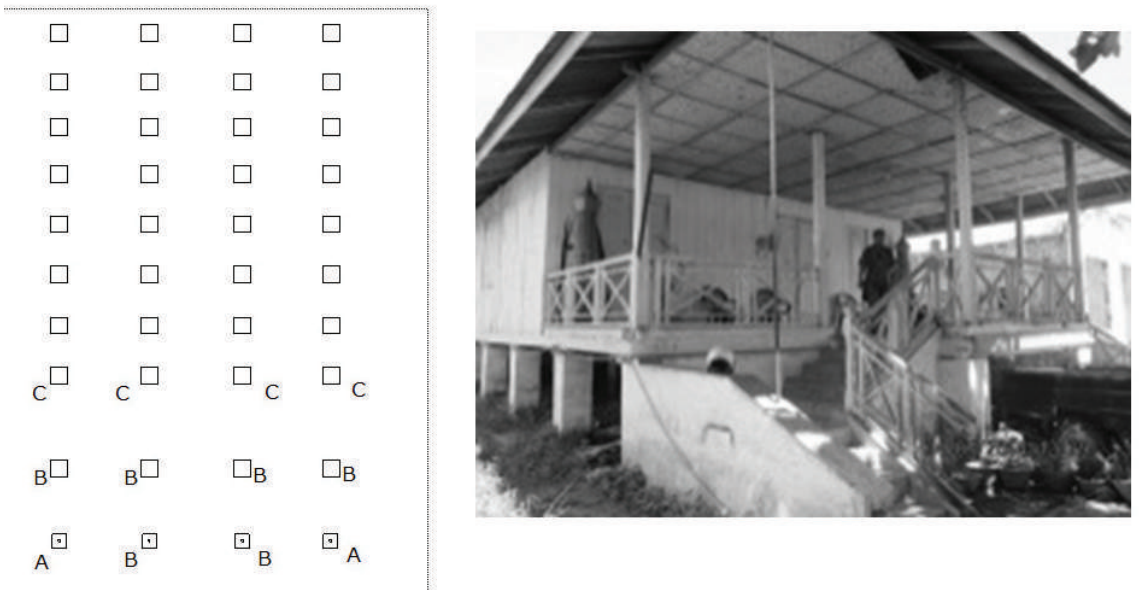

Gambar 3. Makna Jumlah Tiang pada Komposisi Tiang Dasar dan Tiang Penopang Atap Teras

Angka 2 pada atap bersusun dua, melambangkan adat dan syariat. Atap pada lapis pertama melambangkan adat, dimana pelaksanaannya harus dimulai dari para pembesar negeri termasuk raja dan para pemangku adat, lapis kedua melambangkan syariat yang diawali dari para imam, hakim, dan pegawai syara', dimana keduanya harus seiring sejalan dalam pelaksanaan kehidupan sehari-hari. Angka lima melambangkan rukun Islam serta 5 prinsip hidup masyarakat gorontalo, yaitu: Bangusa talalo, Lipu poduluwalo, Batanga pomaya, Upango potombulu, Nyawa podungalo, artinya keturunan dijaga, negeri dibela, diri diabdikan, harta diwakafkan/dikorbankan, nyawa taruhannya. Angka 6 selain melambangkan rukun iman angka 6 juga mempunyai makna 6 sifat utama atau ciri masyarakat lou dulowo limo lopahala'a yaitu: (1) sifat tinepo-tenggang rasa, (2) sifat tombulao-hormat, (3) sifat tombulu-bakti kepada penguasa, (4) sifat wuudu-sesuai kewajaran, (5) sifat adati-patuh kepada peraturan, (6) sifat butoo-taat pada keputusan hakim. Angka 7 bermakna 7 tingkatan nafsu yang mengangkat harkat dan martabat manusia, yakni: nafsu amarah, nafsu lauwamah, nafsu mulhimah, nafsu muthmainnah, nafsu rathiah, nafsu mardhiah, dan nafsu kamilah. Filosofi angka 7 ini juga berlaku pada struktur dan konstruksi bagian bawah (kolong), tengah (badan) rumah, dan atas (atap). 

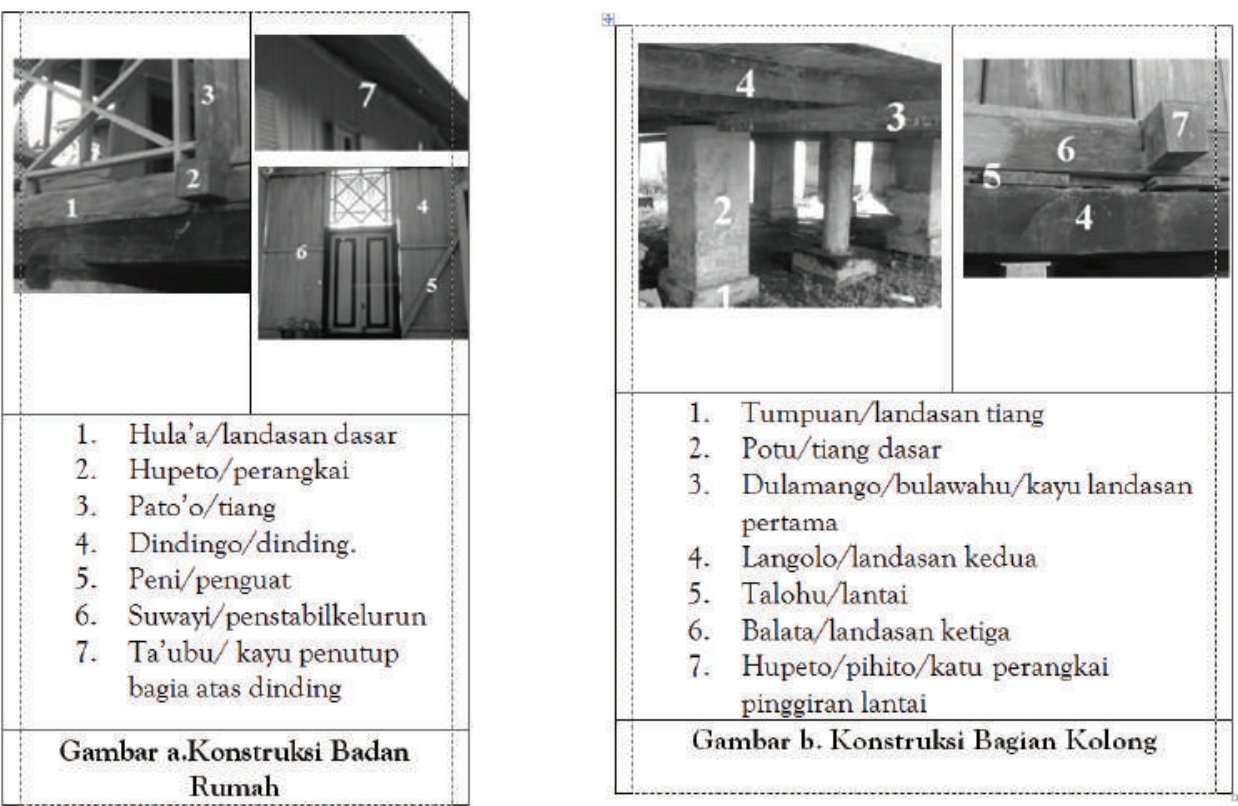

Gambar 4. Makna Angka 7 di Bagian Struktur dan Konstruksi Badan Rumah (a), Struktur dan Konstruksi Kolong (b)

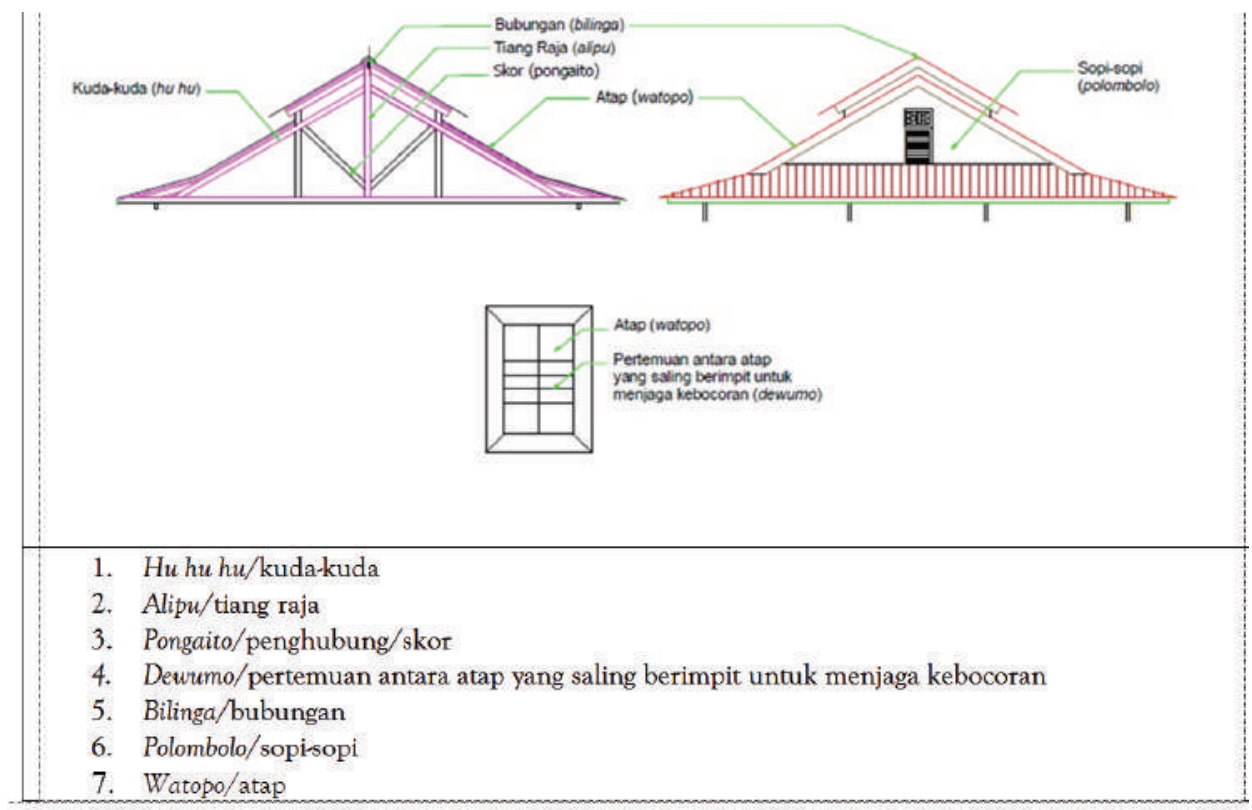

Gambar 5. Makna Angka 7 di bagian Struktur dan Konstruksi Bagian Atap

el Harakah Vol.16 No.2 Tahun 2014 
2. Bagaimana masyarakat Gorontalo berelasi dengan alam yang merupakan makna berserah diri manusia, sehingga bentuk dari kegiatan pasrah ini diwujudkan pada rumah yang berbentuk panggung sebagai bentuk adaptasi terhadap lingkungan yang sering banjir, penggunaan material disesuaikan dengan penempatan bahan tersebut pada bagian struktur (struktur bawah, tengah, dan atas), bukaan-bukaan yang tinggi dan lebar, atap pada bagian teras yang menjorok ke luar sebagai bentuk adaptasi terhadap kondisi alam yang beriklim tropis, tata letak bangunan pada tapak-orientasi bangunan dengan alam, tata lansekap-spasial dan lain-lain. Keseluruhan bentuk-bentuk tersebut sebagai adaptasi terhadap kondisi geologi, geografi topologi, dan iklim wilayah Gorontalo.

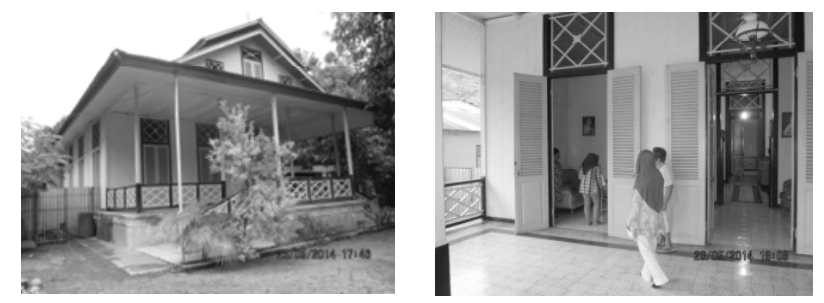

Gambar 6. Makna Relasi dengan Alam Pada Bentuk Rumah Panggung Gorontalo

3. Bagaimana masyarakat Gorontalo berelasi dengan masyarakat yang merupakan penyatuan satu tujuan nilai-nilai luhur (kebaikan) terhadap diri manusia. Budaya ramah yang menjadi ciri khas masyarakat Gorontalo tercermin pada kata matoduolo "disilahkan" mengandung makna budaya ramah masyarakat kepada orang yang datang ke Gorontalo. Budaya ramah merupakan warisan budaya masyarakat Gorontalo dahulu yang terus dipelihara, dijaga dan direfleksikan masyarakat Gorontalo pada masa kini dalam kehidupan bermasyarakat, sehingga bentuk dari penyatuan nilai-nilai ini diwujudkan dalam bentuk penggunaan tangga pada dua arah (Gambar 7a), teras yang lebar sebagai tempat menyambut tamu sebelum masuk ke dalam rumah (Gambar 7b) serta orientasi rumah yang menghadap ke jalan. Bentuk atapnya yang bersusun dua (Gambar $7 \mathrm{c}$ ), menurut tokoh adat Hamid D. Latu; lapis pertama melambangkan buwatula bubato; para pembesar negeri, lapis kedua buwatula syara'; imam, hakim, dan pegawai syara'. Untuk lantai yang merupakan badan rumah yang lebih luas melambangkan buwatula bala; pengawal/perwira dan rakyat sebagai bagian dari masyarakat kebanyakan yang harus dilindungi. Filosofi ini juga mendasari bentuk ornamen jalamba bawah (reling tangga ataupun teras). 


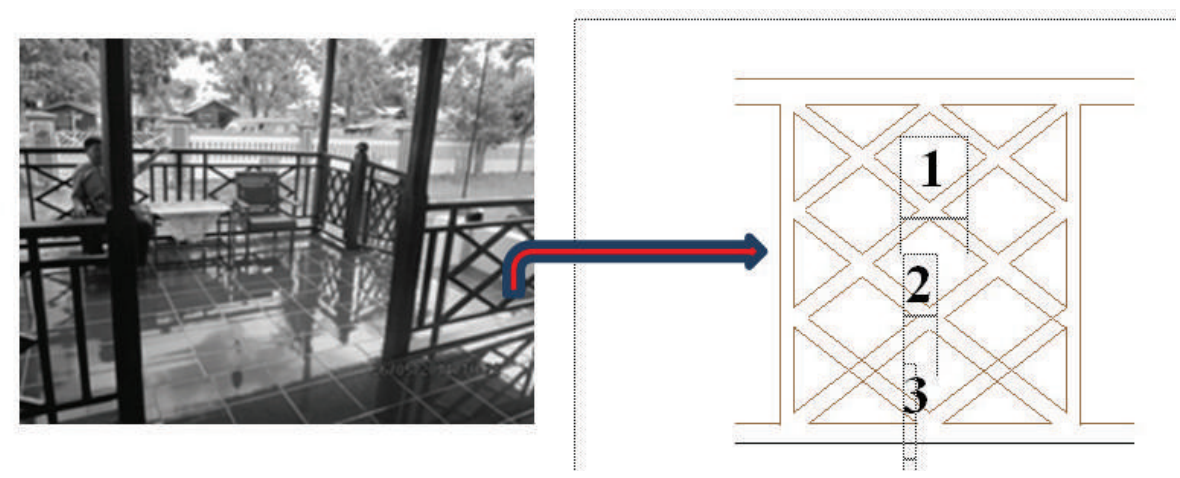

Gambar 7. Makna Urutan Angka pada Ornamen Jalamba

Nilai filosofi pada ornamen pakadangan dilambangkan dengan untaian bunga teratai tampak bagaikan orang yang saling berpegangan tangan sebagai simbol kebersamaan rakyat bahu membahu mendukung rajanya (Gambar 7d). Konsep relasi dengan masyarakat juga tercermin dalam budaya kebersamaan masyarakat Gorontalo pada proses mendirikan rumah yang dilakukan secara bergotong royong (huyula).

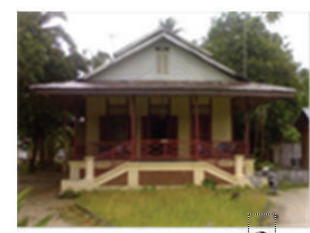

a

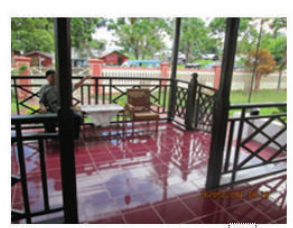

b

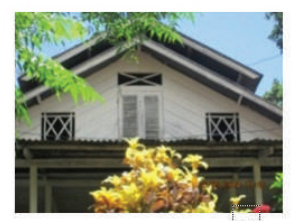

c

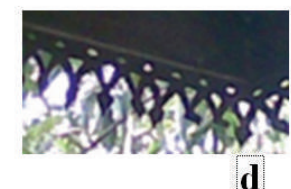

d

Gambar 7. Makna Relasi dengan Masyarakat Pada Elemen-elemen Rumah panggung

Bagaimana masyarakat Gorontalo berelasi sebagai pribadi merupakan bentuk motivasi tekad bulat dalam kegiatan keseharian yang dilakukan di rumah, seperti budaya sopan santun, yang terefleksi pada penempatan kamar tidur orang tua dan anak gadis, anak gadis dan anak laki-laki. Untuk kamar tidur anak laki-laki berada pada bagian depan dan untuk anak perempuan pada bagian belakang. Secara logika, perempuan adalah mahluk yang lemah sehingga harus selalu dijaga dan dilindungi keberadaannya begitu pula keberadaan ruang di bawah atap (loteng) pada zaman dahulu sebagai ruang pingitan anak gadis yang akan dipersunting. Hal ini memperlihatkan tingginya penghargaan 
terhadap para perempuan dalam kehidupan masyarakat masa lalu. Sikap ini terungkap dalam tata ruang vertikal maupun horizontal.

Menurut Farhah Daulima (budayawan Gorontalo), perihal keberadaan dapur yang terpisah dari bangunan induk adalah karena dapur adalah rahasia keluarga yang tabu dimasuki oleh orang lain selain anggota keluarga penghuni rumah, juga dimaksudkan agar para budak atau para pekerja tidak harus melewati ruang-ruang pada bangunan induk ketika hendak memasuki dapur, oleh karena itu letak dapur dipisahkan oleh jembatan dengan bangunan induk/utama. Setiap tamu yang bertandang tidak boleh melewati jembatan tersebut. Berdasarkan hasil wawancara dengan AW Lihu (pemangku adat) bahwa bentuk rumah induk yang terpisah dengan dapur, secara horisontal dari depan kebelakang sama dengan analogi bentuk manusia yang terdiri dari kepala (teras/duledehu), badan (ruang tamu, ruang kamar, ruang peralihan), dan kaki (dapur dan ruang-ruang servis). Bagian lain yang terpisah dengan bangunan induk dan dapur adalah KM/WC.

Terdapat keseragaman pada proporsi rumah hal ini disebabkan filosofi yang tekait dengan ukuran rumah baik secara vertikal maupun secara horisontal. Untuk mengukur ketinggian, panjang dan lebar rumah dengan menggunakan depa, dengan aturan 1 depa dikurangi 1 jengkal hasil pengurangan dibagi 8 . Angka 8 memberi makna keadaan yang selalu terjadi pada diri manusia, yakni: rahmat, celaka, beruntung, kerugian, beranak, kematian, umur dan hangus. Jika angka tersebut berakhir pada yang tidak baik maka harus ditambah atau dikurangi satu.
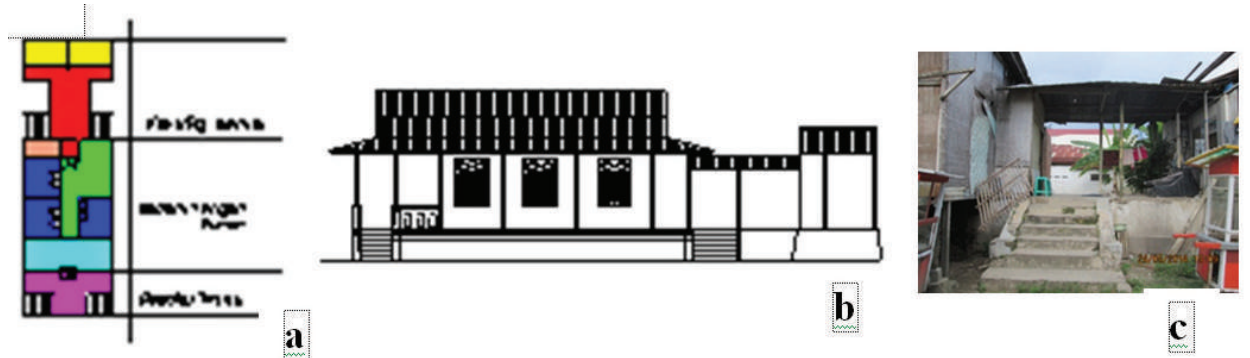

Gambar 8. Makna Relasi dengan Pribadi Pada Bentuk Rumah panggung

(a) Gambar Denah, (b) Gambar tampak samping,

(c) Dokunetasi lapangan

Jika ditelusuri secara mendalam keempat relasi yang disebutkan di atas pada hakekatnya mengandung nilai-nilai Islam sebagai cermin falsafah hidup masyarakat Gorontalo Adati hula-hula'a to sara'a, sara'a hula-hula'a to kuru'ani, 
berarti 'adat bersendikan syarak, syarak bersendikan kitabullah'. Nilai-nilai filosofi mulai dari proses mendirikan rumah sampai pada saat mendiami rumah, pengaruh Islam dalam nuansa budaya lokal tetap terefleksi dalam wujud simbol-simbol seperti pada bagian atap, tangga, sistem struktur, tata ruang, penggunaan ornamen dan lain-lain.

\section{Simpulan}

Wujud konsep kearifan lokal pada arsitektur vernakular Gorontalo terekspresi melalui bentuknya yang bergaya kolonial. Hal ini merupakan konsep model pada arsitektur vernakular yang mengacu pada periodesasi sejarah, dimana dalam proses penyusunannya dipengaruhi oleh nilai-nilai budaya dan nilai-nilai Islam. Nilai-nilai ini secara substantif dapat dilihat dari pesan-pesan moral yang tertuang pada setiap elemen-elemen rumah panggung.

Unsur kearifan lokal dalam arsitektur vernakular Gorontalo (arsitektur rumah panggung) terlihat pada sistem spasial, sistem fisik, sistem model.

Tabel 2. Keterkaitan Konsep Vernakular, Sikap Masyarakat Gorontalo dengan Pemaknaan pada Tipologi Bentuk Rumah Panggung Gorontalo dalam Konsep Kearifan Lokal

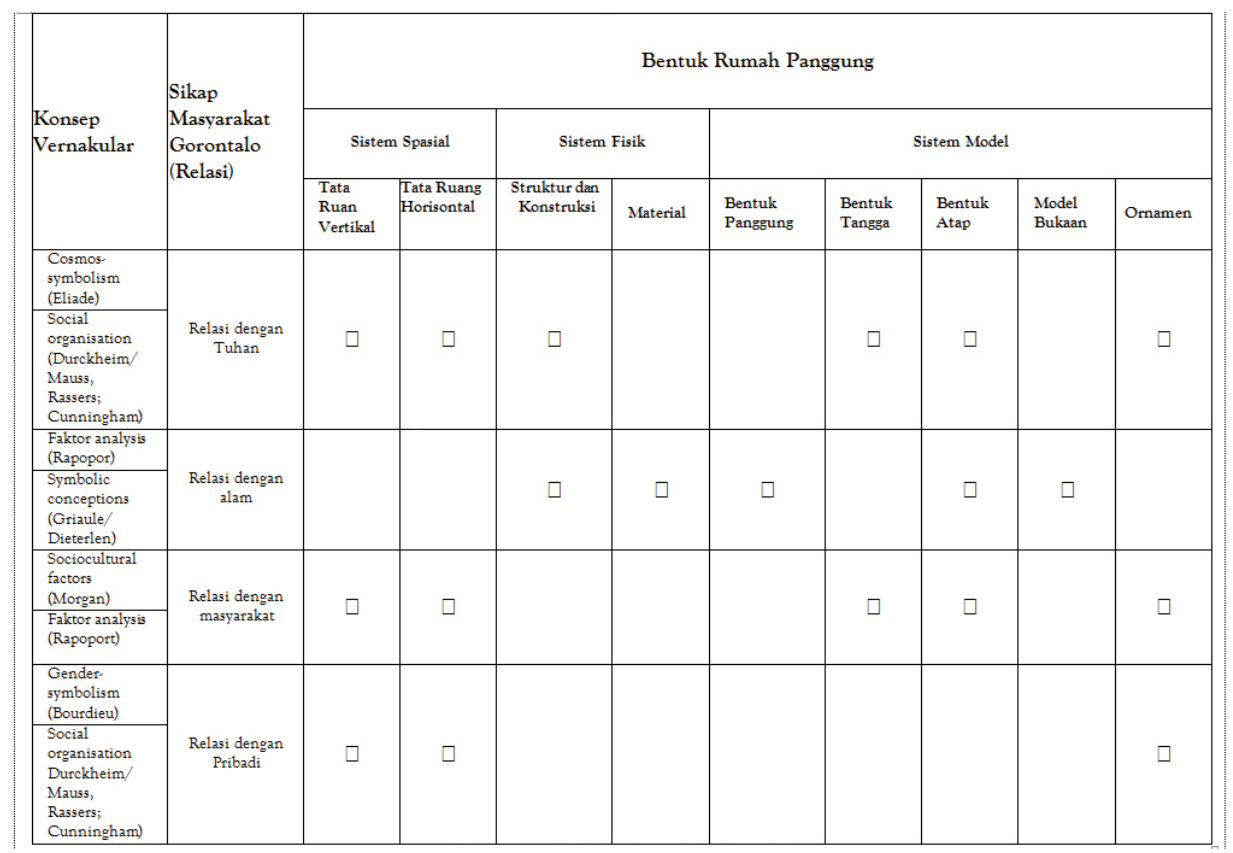

Sumber : Heryati (2014:112) 


\section{Daftar Pustaka}

Allsopp, Bruce. 1977. A Modern theory of Architecture. London: Routledge

\& Kegan Paul Ltd.

Baruadi, Moh. Karmin. 1912 . Sendi Adat dan Eksistensi Sastra; Pengaruh Islam Dalam Nuansa Budaya Lokal Gorontalo. El Harakah. Volume 14, Nomor 2: 293-311.

BPS. 2013. Provinsi Gorontalo Dalam Angka. Gorontalo: BPS.

Correa, Charles-Ken Yeang. 1983. Architecture and Identity. Singapura: Media ltd.

Capon, D.S., 1999. Architectural Theory: The Vitruvian Fallacy, John Wiley \& Son, New York.

Daulima, Farhah \& Pateda, Karim, 2004. Banthayo Pobo'ide: Struktur dan Fungsinya. Limboto: Forum Suara Perempuan.

Daulima, Farhah, 2006. Terbentuknya Kerajaan Limboto-Gorontalo. Limboto: Galeri Budaya Daerah LSM "Mbui Bungale

Heryati. 2014. Transformasi Arsitektur Vernakular Gorontalo Pada Bangunan Masa Kini Untuk Memperkuat Identitas Daerah [Laporan Penelitian]. Gorontalo: Universitas Negeri Gorontalo.

Ibrahim, P. 1990. Proses Masuk dan Berkembangnya Agama Islam di Gorontalo. STKIP Gorontalo.

Mentayani, Ira dan Ikaputra. 2012. Menggali Makna Arsitektur Vernakular: Ranah, Unsur, dan Aspek-Aspek Vernakularitas. LANTING Journal of Architecture. Vol 1 No 2 Halaman 68-82: Universitas Lambung Mangkurat.

Nasr, Sayyed Hossein. 1973. The sense of Unity. London: The University of Chicago press.

Nur, S.R. 1979. Beberapa Aspek Hukum Adat Tata Negara Kerajaan Gorontalo pada masa Sultan Eyato. Ujung Pandang: UNHAS.

Sartini. 2004. Menggali Kearifan Lokal Nusantara Sebagai Kajian Filsafat. Jurnal Filsafat. Jilid 37, Nomor 2 hal. 111-120. http://dgi-indonesia. 
com/wp-content [Diakses 8 September 2001.

Tohopi, Ridwan. 2012. Tradisi Perayaan Isra' Mi'raj Dalam Budya Islam Lokal Masyarakat Gorontalo. El Harakah. Volume 14, Nomor 1: 135-155

Wiranto. 1999. Arsitektur Vernakular Indonesia. Dimensi Teknik Arsitektur. Volume 27, Nomor 2: 15-20.

el Harakah Vol.16 No.2 Tahun 2014 